\title{
The Impact of Rangeland Condition and Trend to the Grazing Resources of a Semi-arid Environment in Kenya
}

\author{
P.N. Macharia ${ }^{1}$ and W.N. Ekaya ${ }^{2}$ \\ 1. KARI - Kenya Soil Survey, P.O. Box 14733, 00800 Nairobi, Kenya \\ Telephone: 254-20-4440903; Fax: 254-20-4444144; Email: kss@iconnect.co.ke \\ 2. Department of Range Management, University of Nairobi, P.O. Box 29053, Nairobi, Kenya \\ Email: ekaya@africaonline.co.ke
}

KEYWORDS Grazing Pressure. Vegetation Degradation. Deforestation. Bush Encroachment. Community Perceptions

\begin{abstract}
A research study was conducted in Mashuru Division of Kajiado District, Kenya with the objective of analyzing the types of vegetation degradation, their causes and their influence on rangeland condition and trend. The study was conducted through remote sensing tools, ground truthing, interviews, community workshop and literature. The results of the study showed that excessive use of the woody species by humans for woodfuel, building and fencing materials, medicine and ornamentals had led to the deterioration of the rangeland due to a loss of cover, change in plant composition and biodiversity. On the other hand, overgrazing and ecological succession of the grazing lands had led to further vegetation degradation in form of bush encroachment and thickening. These types of vegetation degradation have had an overall effect of loss of grass cover and hence loss of grazing capacity by livestock, especially cattle. The causes of vegetation decrease or increase over the last 30 years have been due to deforestation (trees and shrubs), bush encroachment and thickening, change in plant species composition and natural calamities such as droughts, wild fires and army worm invasions at various times. The overall results indicated that there has been a downward trend in range condition over the last 30 years which has affected the livestock productivity of the area.
\end{abstract}

\section{INTRODUCTION}

The structure or physiognomy of the vegetation in Mashuru Division varies from grasslands to dense wooded shrublands with a few patches of forest on the major hills (Macharia et al., 2001). The people living here depends basically on livestock for their upkeep, food and money. But due to the harsh environmental conditions, they practice semi-nomadic pastoralism as a major strategy of exploiting the grazing and browse resources available in the area. The livestock forms an efficient avenue for conversion of forage into meat, milk and other animal products for the people.

However, the nature and trend of the grazing resources over time had been affected by both biophysical and climatic factors. An earlier report by ASAL (1998) noted that there has been a downward trend in range condition in recent years as a result of frequent droughts, overgra-zing and an increase in utilization of the vege-tation resources by man. A definition of range condition by Stoddart et al. (1955) defined it as the current condition of the range in relation to its potential. The authors add that a range in poor condition which is still deteriorating requires a different treatment from a poor range which is in the process of improving.
In terms of productivity, the vegetation receives the greatest impact during land degradation processes. The results are a loss of vegetation cover and in case of grazing systems like those that dominates Mashuru Division, there is decreased forage for livestock and a consequent reduction in animal products for the sustenance of the human population. It is with the above facts in mind that a research study was conducted in 2001/2 in semi-arid Mashuru Division, Kajiado District with the objective of analyzing the degradation of grazing resources which was characteristic of the division. Further, the study was to analyze the causes of the vegetation degradation and their effects on rangeland condition and trend, with a view to halting the processes for the enhancement of livestock productivity in the division.

\section{MATERIALS AND METHODS}

Study Area: The study was carried out in Mashuru Division, Kajiado District which is characterized by vegetation degradation and low primary production especially during the dry seasons. The area falls under agro-climatic zone $\mathrm{V}$ which is classified as semi-arid (Sombroek et al., 1980) and is characterized by low and erratic bimodal annual rainfall of about $500 \mathrm{~mm}$. 
According to ASAL (1998), approximately $95 \%$ of the people who live here are semi-nomadic pastoralists although some of the people practice agro-pastoralism. After the sub-division of former group ranches into individual land holdings, sedentary pastoralism is taking root, whereby only the healthy livestock and their herders move away, while the rest of the homestead remains.

The bimodal distribution of rainfall does not guarantee year round pasture availability. The livestock keepers are therefore forced to maximize on the availability of pastures during both the short and long rains when there is abundant herbage. This high grazing pressure on the natural pastures results in overgrazing, leading to further degradation of the vegetation resources.

Collection of Data: Remote sensing tools, ground truthing, interviews, literature and a synthesizing community workshop were used to collect data on the nature of vegetation degradation and qualitative rangeland condition and trend. A set of panchromatic black and white photographs (scale 1:50,000) flown in 1967 were interpreted for vegetation structure (physio-gnomy). The aerial photograph interpretations (API) were transferred onto topographical map sheets which formed the field base maps. The fieldwork consisted of ground truthing the API units, boundaries and description of the physio-gnomic units, whereby the interpreted boundaries were either confirmed or re-drawn. The fieldwork was also conducted through interviews of ranch owners, administration personnel and elderly people so as to capture their perceptions on vegetation degradation and rangeland condition and trend. All the information gathered was analyzed and synthesized through a community workshop.

\section{RESULTS AND DISCUSSIONS}

Types of Vegetation Degradation: The results of the aerial photograph interpre-tations and ground truthing indicated that some areas had been affected by loss of vegetation especially the woody component. Other areas showed an increase of shrubs and trees leading to a dense vegetation cover than was depicted on the aerial photographs. Thus the types of vegetation degradation in Mashuru Division can be grouped into two types thus, loss of woody vegetation cover and bush encroachment.

Loss of Woody Vegetation Cover: The removal of economically important trees and shrubs by people, usually for woodfuel and construction of houses is regarded as the first type of vegetation degradation. The impact of rapid human population growth and influx of people into Mashuru Division has resulted in an intensive demand for vegetation resources, with uncontrolled cutting of mainly the woody species. The people argue that they act the way they do because the vegetation resource is freely available, char-coal making is an alternative source of income and they lack alternative options (ASAL, 1998).

On the other hand, the on-going sub-division of group ranches into small individual ranches of between 10 and 60 ha (ASAL, 1990) has resulted as a negative impact on the vegetation resources. The people cut thorny tree branches for use as fencing material of the individual land parcels. These materials are replaced after about 6 months due to the termite menace and vagaries of the weather, thus further contributing to vegetation degradation.

Bush Encroachment and Thickening: This second type of vegetation degradation occurs where indigenous shrubs and trees encroach onto former grassland areas changing them to various forms of shrubbed grasslands. On the other hand, the density of trees and shrubs may increase into shrubbed thickets or various wooded types. Both these processes reduce the relative amount of grass and therefore livestock production. This view is in agreement with the observation by Tiffen et al. (1994) who reported that, in the neighboring Machakos District, there was a marked difference in vegetation structure and composition in lightly and heavily grazed portions of the rangeland. Their research results indicated that there was an increase of woody species after overgrazing, suggesting that grazing plays an important role in structuring the vegetation.

Community's Perception of Range Condition Trend: The results of the respondents interviewed at the synthesis workshop presented qualitative information based on two range condition trends. The first trend is that the vegetation resources have decreased over the last 30 years whereas the other trend is that the vegetation has increased. Both these two lines of thought are true as supported by the results of aerial photograph and topographical map interpre-tations. The results of the community's relative perception on the range condition trend 
in major physiognomic units are presented in Table 1.

Causes of Vegetation Decrease or Increase: The causes of vegetation decrease or increase over the past 30 years can be broken down specifically into the following causes:

1. Deforestation of Woody Types: The main uses of the trees and shrubs are provision of woodfuel, building and fencing materials, making of ornamental walking sticks and clubs, fodder for livestock (especially during the dry season), making furniture, medicine and charcoal. The trees and shrubs are harvested by uprooting, cutting, pruning and removal of the dead or dying trees.

Harvesting of trees by men for paddocking, fencing of cattle bomas, dams and areas under crops and by women for construction of houses has increased in recent years. The rise in human population is causing an increase in utilization of trees, medicine and furniture. Further, the present individual land ownership encourages single household bomas, creating more demand for trees to be used for fencing and building the new bomas. The high demand for trees is accelerated by the fact that the fencing materials are destroyed after a short while.

Charcoal production in the area is on the increase as the presence of many charcoal kilns and charcoal sellers testify. Most of the charcoal is sold to middle men who supply it to other markets. The land owners negotiate with the middlemen a fee to clear a portion of land, whereby the middlemen then engage casual labourers who fell the tress and make charcoal. Efforts to control the felling of trees and making of charcoal have been fruitless because of uncoordinated administrative measures.

2. Natural Ecological Succession: These processes occur where weedy, and then woody pioneer plants such as Acacias invade what was previously open grassland or bare land. Seeds of these plants are dispersed by large herbivores and germinate readily, especially after good rainfall events (Hoffman and Ashwell, 2001). The authors add that, if the seedlings are not destroyed by fire or browsing animals, they grow into mature trees that provide perches for birds with a shady, moist environment beneath them. The next stage in succession takes when bird-dispersed shrubs and trees start to germinate in the shade of the pioneer trees, leading to a bush. The obvious effect of bush encroachment and thickening is to decrease grass production and therefore the grazing capacity of the pasture, particularly for cattle.

Table 1: Community's qualitative perception of range condition trend in Mashuru Division

\begin{tabular}{|c|c|c|c|}
\hline Present physiognomic cover & How it was 30 years ago & Cause of change & Present use \\
\hline \multirow[t]{4}{*}{ Forests and Woodlands } & Less & - Conservation & - Fencing \\
\hline & & - Regeneration & - Construction poles \\
\hline & & - Decrease of wildlife & $\begin{array}{l}\text { - Firewood collection } \\
\text { - Grazing by livestock }\end{array}$ \\
\hline & Bigger in size & $\begin{array}{l}\text { - Tree felling (illegal trade) } \\
\text { - Illegal brewing }\end{array}$ & - Grazing \\
\hline \multirow[t]{3}{*}{ Shrubland } & Less & - Plenty of seeds & - Grazing (maminly goats) \\
\hline & & - Decrease of wildlife & $\begin{array}{l}\text { - Building materials (traditional } \\
\text { huts) } \\
\text { - Fencing materials } \\
\text { - Source of walking sticks and } \\
\text { ornamental clubs }\end{array}$ \\
\hline & Thicker & - Increase of settlements & $\begin{array}{l}\text { - Grazing } \\
\text { - Cultivation }\end{array}$ \\
\hline Grasslands & Plenty and of good quality & $\begin{array}{l}\text { - Increase of livestock due - } \\
\text { to population increase } \\
\text { - Trampling } \\
\text { - Overgrazing }\end{array}$ & $\begin{array}{l}\text { - Grazing } \\
\text { - Cultivation }\end{array}$ \\
\hline \multirow[t]{3}{*}{ Barelands } & Nil & - Drought & - None \\
\hline & & $\begin{array}{ll}\text { - } & \text { Mining } \\
\text { - } & \text { Overgrazing due to } \\
& \text { increase of livestock } \\
\text { - } & \text { More watering points } \\
\text { - } & \text { Termites }\end{array}$ & $\begin{array}{l}\text { - Invasion by unpalatable weeds and } \\
\text { grasses }\end{array}$ \\
\hline & Few but big & $\begin{array}{l}\text { - More individual watering } \\
\text { points }\end{array}$ & - $\quad$ Fenced watering points \\
\hline
\end{tabular}


3. Change in Plant Species Composition: The degree of grazing strongly affects the structure, composition, quality and productivity of rangeland vegetation (Herlocker, 1999). This phenomenon is likely to occur where a concentration of large herds of livestock in relatively smaller areas may lead to overgrazing, trampling and hindrance to vegetation regeneration (ASAL, 1998). The respondents of our study were aware that there had been a change in species composition over time due to intensities of rangeland use in their area.

Another cause of change in composition of plant species had been due to the El Nino rains that occurred in 1997/98. The respondents of our interviews noted that these extraordinary heavy rains caused the increased growth of some grasses e.g. Pennisetum mezianum and also an invasion by strange grasses such as Rottboelia exaltata especially in the areas that were heavily affected by erosion. The respondents observed that some presently occurring species were not present 30 years ago (invaders), while others were there but they had increased (increasers) and others had decreased (decreasers). These three categories of plant species are presented in Table 2.

4. Natural Calamities: These have occurred in various forms over the years, and the most common are droughts, wild fires and army worm invasions.

(i) Droughts: The arid and semi-arid areas are prone to droughts which result in overgrazing of pastures and movement of livestock and people to other areas. In Mashuru Division, this phenomenon occurred during 1952-1955, 1960-1961, 1975/6, 1984, 1994 and 2000 (UNEP and GoK, 2000). Due to prolonged droughts in 1960-1961, there was 70 to $80 \%$ cattle mortality in Maasai land and the people were forced to buy and keep the small stock, which could survive the drought better than cattle due to their grazing/browsing habits. Other reasons were that have quick the small stock is faster in restocking and economic returns than the cattle.

(ii) Wild Fires: These are common during the dry periods and their effect usually worsens the already bad environmental situation. The respondents said that in Mashuru Division, there were serious wild fires during year 2000/1 in some areas where they wiped out vegetation and seeds. Fires mainly affect the regeneration capacity of the shrubs and trees as the grasses are better adapted against fire due to their hidden apical meristems (Too, 1985). As Herlocker (1999) observed, fre-quent burning (yearly) independent of the season, results in a reduction of the perennial grass cover and an increase of the percentage cover of annual grasses, herbs/weeds and bare soil.

(iii)Army Worm Invasions: These have occurred over unspecified periods and the results have been heavy losses of the vegetation resources.

Table 2: Some invader, increaser and decreaser species in Mashuru Division over the last 30 years

\begin{tabular}{|c|c|c|c|}
\hline & Type of species & Vernacular name & Present use \\
\hline \multirow[t]{9}{*}{ A. } & \multicolumn{3}{|l|}{ Invader species } \\
\hline & 1. Commiphora eminii & Ochilishili & Live fencing \\
\hline & Acacia mellifera & Oiti & Fencing (thorny branches) \\
\hline & Astripomoea hildebrandtii & Oltiameleteti & None \\
\hline & Oxygonum sinuatum & Olkurishashi & None \\
\hline & Rottboelia exaltata & (Not available) & Grazing (when young) \\
\hline & Lantana camara & (Not available) & Goat fodder \\
\hline & Gnidia latifolia & Enkopirisiai & Building traditional huts (not attacked by termites) \\
\hline & 8. Solanum arundo & Esikaoi & None \\
\hline \multicolumn{4}{|c|}{ Increaser species } \\
\hline & 1. Cadaba farinosa & Olamalogi & Cattle \\
\hline & Grewia bicolor & Esiteti & Cattle and goats \\
\hline & Balanites glabra & Olng'oswa & Cattle and goats (during dry season) \\
\hline & Ipomoea kituiensis & Oltiameleteti & Donkeys (during dry season) \\
\hline & 5. Pennisetum mezianum & Osankash & Cattle \\
\hline \multirow[t]{7}{*}{ C. } & Decreaser species & & \\
\hline & 1. Indigofera lupatana & Enkoroyei & Cattle \\
\hline & Flacourtia indica & Olleleroi & Cattle \\
\hline & Digitaria macroblephara & Erikaru & Cattle, Sheep and Donkeys \\
\hline & Themenda triandra & Olkujita onyokie & Cattle \\
\hline & 5. Cynodon dactylon & Emurua & All livestock \\
\hline & 6. Grewia tembensis & Eirri & Goats \\
\hline
\end{tabular}




\section{CONCLUSIONS AND RECOMMENDATIONS}

Vegetation dynamics (changes) over time clearly affect the level of biodiversity, conservation status and productivity of rangelands. Other than climate, the principal causes of vegetation degradation in Mashuru Division has been through human activities. In an effort of utilizing the vegetation resources through cutting, grazing and burning, the result has been a negative impact on the rangeland condition. The frequency and intensity of utilization has significantly influenced the vegetation structure, composition, quality and productivity.

Rainfall as the principal climatic factor has its effectiveness in stimulating plant growth. However, this depends on its amount, distribution over time, reliability, and intensity as well as potential evapotranspiration of an area. Droughts, which are a recurring, albeit unpredictable phenomenon, are an inevitable part of the rangeland environment. Droughts may be quite destructive, especially when protracted and may often cause extensive damage to the pastoral economy. Perennial grasses and shrubs may die, thus initiating long-term changes in vegetation composition and structure.

The natural succession towards woody vegetation is constrained by cutting and burning but often assisted by overgrazing. Burning has the most impact in rangeland areas with an abundance of grass biomass which is a form of dry season fuel. Although fires are a valuable rangeland management tool, it can have disastrous results if not managed properly as the degree of impact depends upon the timing and frequency of burning. Burning encourages fire-resistant plants, both woody and herbaceous and more often than not, grasses are better adapted than woody species but some grass species are also more fire-resistant than others.

Sustained overgrazing reduces cover, quality and productivity, changes plant composition from perennial to annual species and encourages bush encroachment. On the other hand, light to moderate grazing may maintain the range in a fairly good condition. Over the short term, large number of livestock can be grazed as long as the ability of the rangeland to recuperate is not reduced. A given number of grazers will affect a rangeland less when distributed over a wide than a small area. Also, continuous grazing is more apt to degrade pasture than when it is given a chance to rest and recover.

\section{REFERENCES}

ASAL: Kajiado District Atlas. Arid and Semi-Arid Lands Programme, Kajiado (1990).

ASAL: Community Level Natural Resource Management Plan for the Central Kajiado Planning Area: The Case of Olobelibel and Oloontulugum. Arid and Semi-Arid Lands Programme, Kajiado (1998).

Herlocker, D. (Ed.): Rangeland Resources in Eastern Africa: Their Ecology and Development. GTZ, Nairobi (1999).

Hoffman, T. and Ashwell, A.: Nature Divided: Land Degradation in South Africa. University of Cape Town, South Africa (2001).

Macharia, P.N., Wagate, P.N. Mulei, B.M., Mulei, B.N., Mulei, P.J. and Humaiya, S.N.: The Vegetation and Land Use of Mashuru Division, Kajiado District. Report R19, Kenya Soil Survey, Nairobi (2001).

Somborek, W.G., Braun, H.M.H and van der Pouw, B.J.A.: Exploratory soil map and agro-climatic zone map of Kenya. Scale 1:1 million. E1 Report, Kenya Soil Survey, Nairobi (1980).

Stoddart, L.A., Smith, A.D. and Box, T.W.: Range Management. McGraw Hill, New York (1975).

Tiffen, M., Mortimore, M. and Gichuki, F.: More People, Less Erosion: Environmental Recovery in Kenya. ACTS Press, Nairobi (1994).

Too, Daniel Kipkoech: Effects of Defoliation Frequency and Intensity on Production of Four Burned and Unburned Bushed Grassland Communities in South-central Kenya. MSc Thesis, Texas A \& M University, USA (1985).

UNEP and GoK: Devastating Drought in Kenya: Environmental Impacts and Responses. United Nations Environment Programme and Government of Kenya (2000). 